\title{
Immunogenetic Bases of Congenital Malformations: Association of HLA-B27 with Spina Bifida
}

\author{
JACEK J. PIETRZYK AND GABRIEL TUROWSKI \\ Clinical Genetics Laboratory, Institute of Pediatrics, and Transplantation Unit, Copernicus Medical Academy, \\ Krakow, Poland
}

\begin{abstract}
Summary
A random sample of 46 families with single and multiple cases of spina bifida has been selected from families referred to the Institute of Pediatrics for genetic counseling. This sample constituted a group of 92 parents and 102 offspring: 41 normal, 46 with spina bifida, and 13 with spina bifida occulta. Routine HLA typing was performed on the parents and their children. For each case, 13 HLA specifities from locus $A$ and 15 from locus $B$ were determined. Segregation analysis in families showed excellent agreement with the expected values. HLA gene frequencies in the affected children as compared with a control population of $\mathbf{2 4 0}$ normal adults, revealed significantly higher frequency for ILLAB27 allele: $\chi^{2}=11.9515, P$ (corrected for the number of alleles) $<0.028$. A significant relative risk of spina bifida development for a given HLA-B27 antigen was 2.7 . In view of the presented results, routine HLA typing might be recommended for genetic counseling as a new tool for identification of high risk families.
\end{abstract}

\section{Speculation}

A number of developmental genes mapped at the $T$ locus in mice may interact in heterozygotes to produce offspring which are tailless or have spina bifida. Close chromosomal proximity of the T locus and the H-2 complex, as well as their evolutionary relationship, suggest that $\mathrm{H}-2$ antigens might be considered as genetic markers of developmental events. The great homology between the $\mathrm{H}-2$ chromosomal region in mice and the human HLA complex suggested the investigations on association between histocompatibility antigens and birth defects in man.

During the last 2 decades, immunoembryology accumulated much evidence that some developmental events are mediated by genetically determined, cell surface components $(3,9,26,32)$. These components termed differentiation alloantigens, were found in gametes and in the human embryo during the early stages of ontogenesis $(3,9,26)$

HLA antigens, determined by four autosomal loci: A, B, C, and $D$, are the best known human alloantigens. It has been proved that HLA antigens may influence susceptibility to certain diseases, however the mechanisms of these relations are still unknown (2, $7,25,30)$. Also, there are suggestions supported by clinical observations that HLA antigens expressed on the surface of gametes may influence their union and zygote development $(12,24)$.

These antigens are responsible for the mother's alloimmunization during pregnancy and production of cytotoxic antibodies, of which the deleterious effect on the fetus is still disputable $(1,13-$ 15, 24).

It has been known for nearly $50 \mathrm{yr}$ that mutuations in the so called $\mathrm{T}$ locus in mice resulted in different kinds of congenital malformations $(4,26)$.
A number of $\mathrm{T}$ alleles may interact in heterozygotes to produce offspring which are tailless or have spina bifida $(4,26,33)$. Close chromosomal proximity of the T locus and the H-2 complex (15 crossover units) means that mutations in alleles of the $T$ system are associated with atypical patterns of inheritance of histocompatibility antigens. Because the H-2 locus of mice and the HLA system of man are greatly homologic, the possibitity of a $T$ locuslike region, closely linked to the HLA complex should be considered (9). Based on this analogy, a search for an association between congenital abnormalities and serologically defined (SD) HLA antigens in man has started.

In 1973, Rappaport and Bach (27) reported an atypical pattern of inheritance of HLA antigens in families with cleft lip/cleft palate malformations. Our own studies performed in a group of 63 children with different congenital malformations revealed an association between these abnormalities and the HLA-Al allele (24). Amos and Ward (I) as well as Mendell et al. (20) showed the

Table 1. Families with children with spina bifida

\begin{tabular}{|c|c|c|c|c|c|}
\hline \multirow[b]{2}{*}{ Sibship size } & \multirow{2}{*}{$\begin{array}{c}\text { Number } \\
\text { of families }\end{array}$} & \multirow{2}{*}{$\begin{array}{c}\text { Number } \\
\text { of off- } \\
\text { spring }\end{array}$} & \multicolumn{2}{|c|}{$\begin{array}{c}\text { Number of affected } \\
\text { children }\end{array}$} & \multirow{2}{*}{$\begin{array}{c}\text { Total } \\
\text { affected }\end{array}$} \\
\hline & & & SB & SBO & \\
\hline 1 & 15 & 15 & 15 & & 15 \\
\hline 2 & 17 & 34 & 17 & 3 & 20 \\
\hline 3 & 8 & 24 & 8 & 2 & 10 \\
\hline 4 & 3 & 12 & 3 & 3 & 6 \\
\hline 5 & 1 & 5 & 1 & 0 & 1 \\
\hline 6 & 2 & 12 & 2 & 5 & 7 \\
\hline Total & 46 & 102 & 46 & 13 & 59 \\
\hline
\end{tabular}

linkage between spina bifida and the HLA complex, however, no evidence of association was found by Bobrow et al.(6).

To check the hypothesis on the evolutionary relationship between a $T$ locuslike region and the HLA complex in man, the sample of 46 families with single and multiple cases of spina bifida (SB) and spina bifida occulta (SBO) were studied.

\section{MATERIALS AND METHODS}

Forty-six families with children with $\mathrm{SB}$ registered during the studies on the epidemiology of congenital malformations and referred to the Institute of Pediatrics, Copernicus Medical Academy in Krakow, Poland for treatment and/or for genetic counseling during the period 1970-1976 were studied (10).

This sample constituted 102 offspring: 46 living index cases and 56 normal sibs. An x-ray examination of the lumbo-sacral region performed among 56 apparently normal sibs revealed 13 cases of SB. Based on the assumption, that SB and SBO represent the 
Table 2. Segregation of HLA haplotypes in 46 families

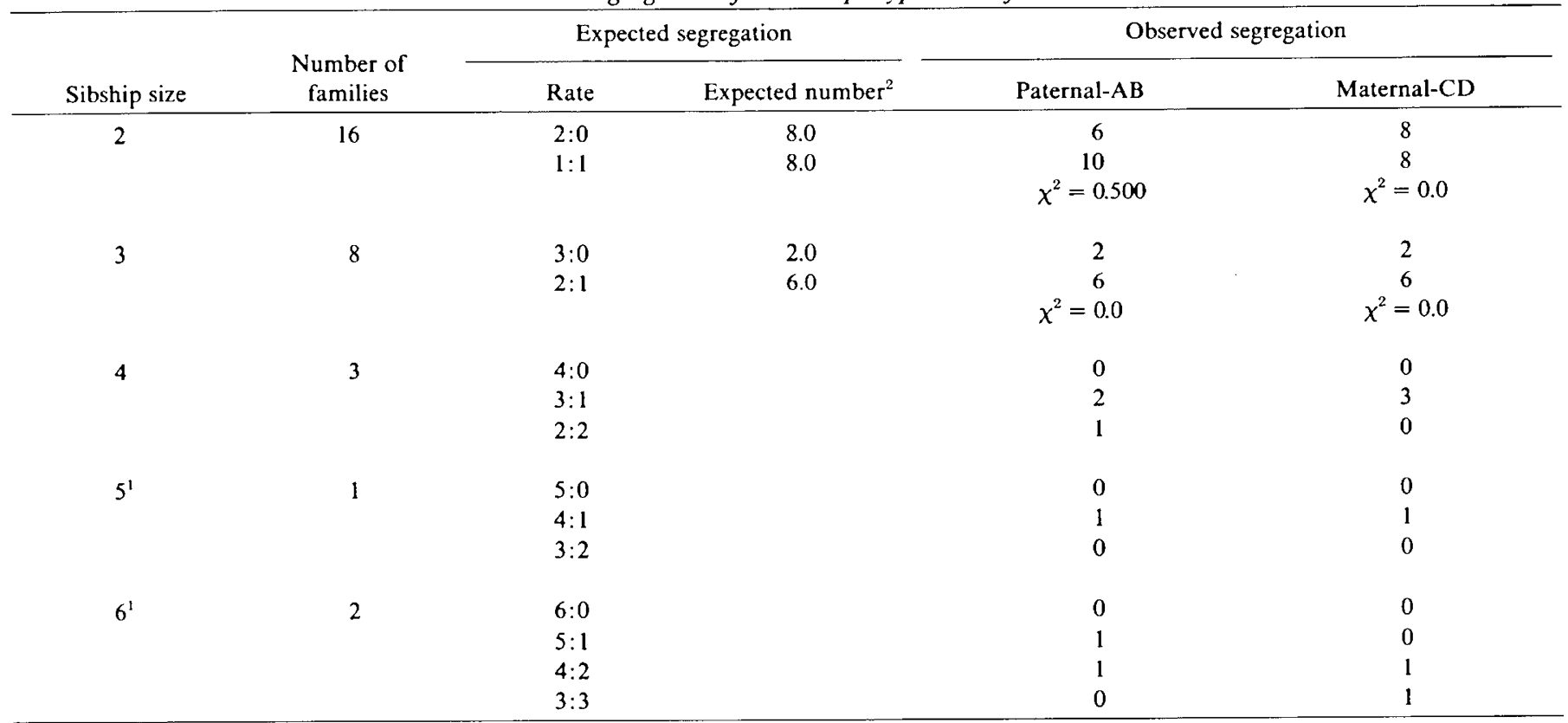

${ }^{1}$ For families of size 4,5 , and $6, \chi^{2}$ was not computed because of small numbers.

${ }^{2}$ Expected numbers of families with given segregation rate was computed on the basis of binomial distribution:P=( $\left.\begin{array}{l}n \\ k\end{array}\right) \cdot p^{k} \cdot(1-p)^{n-k}$ where $n$ $=$ sibship size, $\mathrm{k}=$ number of children receiving the same haplotype, and $P=$ probability of segregation of given haplotype. In families of size 3 for example, the probability that all children have received the same haplotype from one parent (segregation 3:0 or 3:0) is

$$
2 \cdot\left(\begin{array}{l}
3 \\
3
\end{array}\right) \cdot\left(\frac{1}{2}\right)^{3} \cdot\left(\frac{1}{2}\right)^{0}=2 \cdot \frac{3 !}{3 ![3-3] !} \cdot \frac{1}{8}=\frac{1}{4}
$$

Table 3. HLA gene frequencies in children with $S B$ and $S B O$ compared with the control population

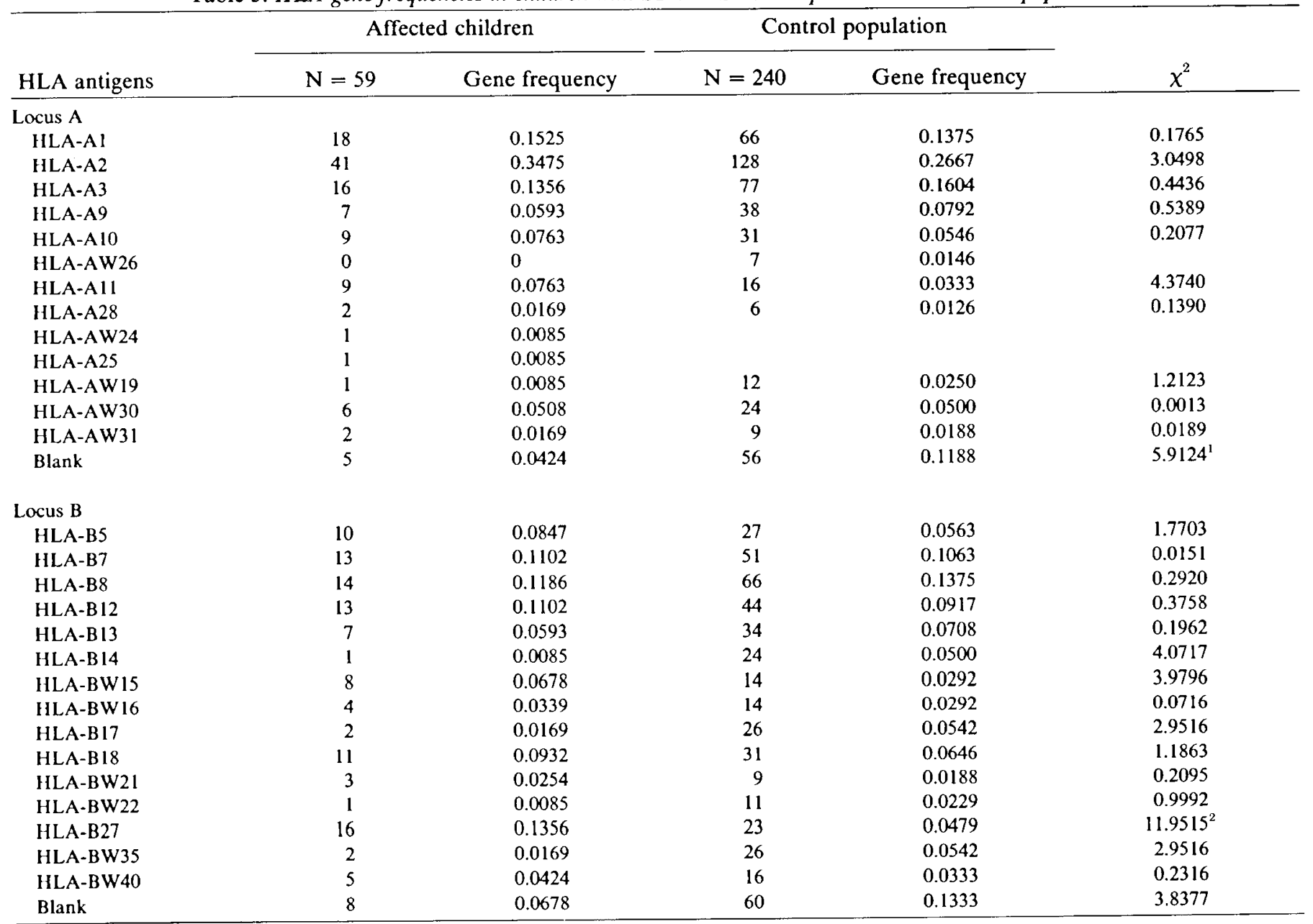

' $P \sim 0.725$.

${ }^{2} P<0.028$ (corrected for the number of alleles tested). 
Table 4. Haplotype frequencies $\times 10^{4}$ in 59 children with $S B$ and $S B O$

\begin{tabular}{|c|c|c|c|c|c|c|c|c|c|c|c|c|c|c|c|c|c|}
\hline & & \multicolumn{16}{|c|}{ HLA-B } \\
\hline \multicolumn{2}{|l|}{ HLA-A $^{1,2}$} & HLA-B5 & HLA-B7 & HLA-B8 & HLA-B 12 & HLA-B 13 & HLA-B 14 & HLA-B 18 & HLA-B27 & HLA-BW15 & HLA-BW16 & HLA-BW17 & HLA-BW2I & HLA-BW22 & HLA-BW35 & HLA-BW40 & Blank \\
\hline \multirow{2}{*}{ HLA-A I } & $\mathbf{n}$ & 3 & & 12 & & & & 1 & 1 & & & 1 & & & & & \\
\hline & f & 254 & & 1017 & & & & 85 & 85 & & & 85 & & & & & \\
\hline \multirow{2}{*}{ HLA-A2 } & $\mathrm{n}$ & 3 & 3 & 1 & 12 & 3 & & 3 & 4 & 2 & 1 & & 1 & & 1 & 2 & 5 \\
\hline & $\mathrm{f}$ & 254 & 254 & 85 & 1017 & 254 & & 254 & & 169 & 85 & & 85 & & 85 & 169 & 424 \\
\hline \multirow{2}{*}{ HLA-A3 } & $\mathrm{n}$ & & 6 & & & & & 1 & 6 & & & & & & 1 & 1 & 1 \\
\hline & f & & 508 & & & & & 85 & 508 & & & & & & 85 & 85 & 85 \\
\hline \multirow{2}{*}{ HLA-A9 } & $\mathrm{n}$ & & & & & & 1 & 1 & & 3 & 1 & & & & & 1 & \\
\hline & $\mathrm{f}$ & & & & & & 85 & 85 & & 254 & 85 & & & & & 85 & \\
\hline \multirow{2}{*}{ HLA-A 10} & $\mathrm{n}$ & & 1 & 1 & & 1 & & 1 & 2 & 1 & 1 & & 1 & & & & \\
\hline & f & & 85 & 85 & & 85 & & 85 & 169 & 85 & 85 & & 85 & & & & \\
\hline \multirow{2}{*}{ HLA-All } & $\mathbf{n}$ & 2 & 1 & & & & & 2 & 1 & 1 & & & & 1 & & 1 & \\
\hline & f & 169 & 85 & & & & & 169 & 85 & 85 & & & & 85 & & 85 & \\
\hline \multirow{2}{*}{ HLA-A28 } & $\mathrm{n}$ & 1 & & & & & & & 1 & & & & & & & & \\
\hline & $\mathrm{f}$ & 85 & & & & & & & & & & & & & & & \\
\hline \multirow{2}{*}{ HLA-AW19 } & $\mathrm{n}$ & 1 & & & & & & & & & & & & & & & \\
\hline & f & 85 & & & & & & & & & & & & & & & \\
\hline \multirow{2}{*}{ HLA-AW24 } & $\mathrm{n}$ & & & & & & & & & & & 1 & & & & & \\
\hline & f & & & & & & & & & & & 85 & & & & & \\
\hline \multirow{2}{*}{ HLA-AW 25} & $\mathrm{n}$ & & & & 1 & & & & & & & & & & & & \\
\hline & f & & & & 85 & & & & & & & & & & & & \\
\hline \multirow{2}{*}{ HLA-AW 30} & $\mathrm{n}$ & & & & & 3 & & 2 & & & · & & & & & & 1 \\
\hline & f & & & & & 254 & & 169 & & & & & & & & & 85 \\
\hline \multirow{2}{*}{ HLA-AW31 } & $\mathrm{n}$ & & & & & & & & 1 & 1 & & & & & & & \\
\hline & f & & & & & & & & 85 & 85 & & & & & & & \\
\hline \multirow[t]{2}{*}{ Blank } & $\mathrm{n}$ & & 2 & & & & & & & & 1 & & 1 & & & & 1 \\
\hline & $\mathrm{f}$ & & 169 & & & & & & & & 85 & & 85 & & & & 85 \\
\hline
\end{tabular}

' $n$, observed number.

${ }^{2} \mathrm{f}$, haplotype frequency. 
same genetic entities, depending on different expression of the deleterious genes, both conditions were studied together $(10,17$, $18,21)$. Table 1 characterizes all families according to their size and number of SB and SBO children.

\section{TISSUE TYPING}

HLA typing for serologically defined antigens, locus A and B, were performed in 92 parents and 102 children. By routine lymphocytoxicity micromethod, 13 specifities of HLA-A locus and 15 of HLA-B locus were determined (23). Standard sera were obtained from NIAID, Genetics and Transplantation Biology Branch (22). For each specifity, at least two antisera were used. Every case with a doubtful result was typed for the second time.

\section{COMPUTATIONS}

HLA haplotypes and genotypes were inferred from segregation in families. Then HLA genes and haplotype rrequencies in the $\mathrm{SB}$ and SBO offspring were estimated by direct gene counting method. A routine segregation analysis were performed (19). Gene and haplotype frequencies in the group of 59 affected children were compared with the same frequencies in the control population of 240 unrelated, normal adults from the same region of Poland by the $\chi^{2}$ method (31). Relative risk for development of SB condition given particular HLA antigen was computed according to Svejgaard et al. (29).

\section{RESULTS}

The results of routine HLA segregation analysis in the group of 46 families are shown in Table 2. Segregation of HLA haplotype in families with two and three offspring revealed an excellent agreement with the expected values for Mendelian inheritance pattern. For families with four and more children, the rigorous statistical analysis was avoided, because of small numbers. Gene frequencies in the group of 59 affected children and in the control population are indicated in Table 3. Case control comparisons revealed a nominally significant difference for the HLA-B27 allele, which frequency was higher in the study group than in the control: $\chi^{2}=11.9515 P<0.027$ (corrected for the number of alleles tested.).

Significant relative risk for development of the SB condition, given HLA-B27 antigen was equal to 2.7 .

The group of 59 affected children made 118 haplotypes. Absolute values and frequencies of observed haplotypes are shown in the Table 4. The most frequent haplotypes were:HLA-Al, B8; HLA-A3, B7; HLA-A2, B12; and HLA-A3, B27. The first three haplotypes are generally reported as the most frequent in nearly all caucasian populations. They were also most frequent in the control population (30). It should be mentioned, that the frequency of the HLA-A3, B27 haplotype was relatively higher in the study group than in the controls. The difference, however, was not significant.

\section{DISCUSSION}

There are many reports in the literature on the HLA disease association summarized by Dausset (7). Dausset and Svejgaard (8), and Turowski and Pietrzyk $(25,30)$. An association, whether strong or weak, implies a genetic contribution to etiology of the particular discase. The hypotheses explaining the mechanisms of observed associations suggest either that the given HLA antigen is the disease susceptibility gene product or that this gene and HLA allele show such a tight linkage disequilibrium, that they can not be distinguished $(5,7)$. The first hypothesis is consistent with the speculation on evolutionary relationship between $T$ locus genes and $\mathrm{H}-2$ alleles $(4,26)$.

Recent studies demonstrated that the $T$ locus is located on the chromosone no. 17 , and that there are approximately six $\mathrm{T}$ subloci closely linked to each other. Genes determined by the $T$ locus specify cell surface antigens present on sperm and on embryos and thus, they appear to be in this respect similar to $\mathrm{H}-2$ genes. There are speculations, that the set of $\mathrm{T}$ genes govern cell-to-cell recognition during early phases of ontogenesis, and that a duplication of these genes which occurs later provides genes of the histocompatibility complex. It means, that $\mathrm{T}$ locus genes might be the evolutionary precursors of $\mathrm{H}-2$ complex in mice. Present evidence that $\mathrm{T}$ locus gene products are detected only in very young embryos whereas $\mathrm{H}-2$ gene products are present on the cells of old embryos and adults, supports this idea $(4,33)$. Mice which are homozygous for mutations at most of these loci die in embryonic or fetal life with major morphologic abnormalities. Most of the observed abnormalities involve ectodermal and nervous structures including the primitive streak notocord, neural tube, and brain. The time of lethality as well as the spectrum of congenital malformations depends on the number of mutations at particular loci $(4,9,26,33)$.

The results of presented studies revealed significant association between the SB condition and HLA-B27 allele. It might be interesting in the view of very strong association observed for HLA-B27 and ankylosing spondylitis disease with familial incidence and which affects the spine $(7,8,25)$.

It would be very risky to draw any inference from this coincidence, however, the results of Shapiro et al (28), who showed an association between HLA-B27 and modified formation of spine bones may suggest that this coincidence is not casual.

The association between HLA and neural tube malformations suggests that HLA complex may be involved in the etiology of congenital malformations. However, because these anomalies are multifactorial in origin, histocompatibility antigens and other differentiation alloantigens might only constitute a predisposing factor. Pious (26) suggests, that it would be reasonable to characterize surface antigens (e.g., HLA) in human sperm and to search for the presence of peculiar antigens in patients with congenital malformations. Then, it might be possible to separate sperm bearing given "developmental antigen"by using a cytotoxic test, thus, avoiding malformation of the embryo. (26). If further investigations confirm the association of the HLA system with birth defects, then tissue typing will create a new practical tool for identification of high risk families in genetic counseling.

In the view of these speculations, presented results together with the previous findings of other authors are of sufficient interest to warrant further investigation on the association of the HLA system with birth defects in man.

\section{REFERENCES AND NOTES}

1. Amos, D. B., and Ward F. E.: Immunogenetics of the HLA system. Physiol. Rev., 55: $206(1975)$

2. Bach, F. H., and Van Rood, J. J.: The major histocompatibility complexgenetics and biology. N. Engl. J. Med., 295: 806 (1976).

3. Beer, A. E., and Billingham R. E.: Concerning the origins and scope of the immunology of mammalian reproduction. Transplant. Proc., 9: 1357 (1977).

4. Bennett, D.: The T-locus of the mouse. Cell., 6: 441 (1975).

5. Bias, W. B., and Chase G. A.: Genetic implications of HLA and disease association. Transplant. Proc., 9: 531 (1977).

6. Bobrow, M., Bodmer, J. G., Mc Devitt, H. O., Lorber, J., and Swift, P.: The search for a human equivalent of the mouse $T$-locus - negative results from a study of HLA types in spina bifida. Tissue Antigens, 5: 234 (1975).

7. Dausset, J.: HLA complex in human biology in the light of associations with disease. Transplant. Proc., 9: 523 (1977).

8. Dausset J., and Svejgaard A., (editors): HLA and Disease. (Copenhagen, Munksgaard, 1977)

9. Erickson, R. P.: Differentiation alloantigens, histocompatibility loci, and birth defects. Am. J. Hum. Genet., 27: 554 (1975).

10. Gardner, R. J. M., Alexander, C., and Veale, A. M. O.: Spina bifida occulta in the parents of offspring with neural tube defects. J. Génét. Hum., 22: 389 (1974)

11. Kańska, B., Konik, R., and Pietrzyk, J. J.: Environmental, cytogenetic and clinical-biochemical studies on selected congenital malformations. Encephalomyelocele. In: Epidemiology of Congenital Malformations in Kraków Region. (RSW-Prasa-Ksiazka-Ruch, Kraków, 1974).

12. Karèk, G., and Afzelius, B. A.: The HLA antigens on human spermatozoa. Int. J. Fertil., 17: 120 (1972).

13. Kissmeyer Nielsen, F., Jorgensen, F., and Lamm, L. U.: The HLA system in clinical medicine. Hopkins Med. J., J31: 385 (1972).

14. Kobielowa, Z., Turowski, G., and Pietrzyk, J. J.: Lymphocytotoxine frequency 
and HLA typing in small for date children. Pol. Med. Sci. Hist. Bull., 15: 75 (1975).

15. Kobielowa, Z., Turowski, G., Pietrzyk, J. J., and Michalik, R.: L'immunisation anti-HLA et la maturation immunitaire des enfants avec le retard de croissance intra-uterin. XXIII Congres de l'Association des Pédiatres de langue francaise. Communications, Allier-Grenoble, 5: 217 (1972).

16. Laurence, K. M., Bligh, A. S., Evans, K. T., and Shurtleff, D. B.: Vertebral abnormalities in parents and sibs of cases of spina bifida cystica, encephalocele and anencephaly, Proceedings of the 13-th International Congress of Pediatrics, 2: 415 (1971).

17. Lorber, J.: The family history of spina bifida cystica. Pediatrics, 35: 589 (1965).

18. Lorber, J., and Levick, K.: Spina bifida cystica. Incidence of spina bifida occulta in parents and in controls. Arch. Dis. Childhood, 42: 171 (1967).

19. Mattiuz, P. L., Ihde, D., Piazza, A., Ceppellini, R., and Bodmer, W. F.: New approaches to population genetic and segregation analysis of the HLA system. In: P. I. Terasaki: Histocompatibility Testing. p. 193 (Copenhagen, Munksgaard, 1970).

20. Mendell, N. R., Johnson, A. H., Ruderman, R. J., Amos, D. B., and Yunis, E. J: Spina bifida and the HLA system: evidence for linkage. Am. J. Hum. Genet. 26: 60A (1974)

21. Miller, J. R., Fraser, F. C., and Mc Ewan, D. W. The frequency of spina bifida occulta and rib anomalies in the parents of children with spina bifida aperta and meningocoele. Am. J. Hum. Genet., 14: 245 (1962).

22. NIAID Catalog of Tissue Typing Antisera 1976-1977, Edited by D. B. Hare $e t$ al. NIH, Bethesda, MD, USA (1976-1977).

23. NIAID Manual of Tissue Typing Techniques, Edited by J. G. Ray et al., NIH.
Bethesda, MD, USA (1976)

24. Pietryk J. J. Study of the HLA system in children with congenital malformations. Proceedings of Symposium on Medical Genetics, Debrecen, Hungary 1976. p. 851 (Excerpta Mediaca, Amsterdam, 1976).

25. Pietrzyk J. J., and Turowski G.: Antygeny HLA: genetyczne determinanty choroby. Pol. Arch. Med. Wewn., 55: 487 (1976).

26. Pious, D.: Cell surfaces genetics and congenital malformations. J. Pediatr., 86 : 162 (1975).

27. Rappaport, F. T., and Bach, F. H.: Genetic studies of cell surface determinants in human developmental anomalies-a preliminary report. Transplant. Proc. 5: 1139 (1973).

28. Shapiro, R. F., Wiesner, K. B., Bryan, B. L., Utsinger, P. D., Resnik, D., and Castles, J. J.: HLA-B27 and modified bone formation. Lancet, I. 230 (1976).

29. Svejgaard, A., Jersild, C., Nielsen, L. S., and Bodmer, W. F.: HLA antigens and disease. Statistical and genetical considerations. Tissue Antigens, 4: 95 (1974).

30. Turowski, G., and Pietrzyk, J. J.: Antygeny zgodności tkankowej HLA i ich związek z chorobą nowotworową. Pat. Pol., 28: 17 (1977).

31. Turowski, G., and Pietrzyk. J. J.. HLA gene and haplotype frequencies in Polish Population. Arch. Immunol. Ther. Exper. (in press) (1979).

32. Willis, R. A.: The Borderland of Embryology and Pathology, (London, Butterworth, 1962).

33. Wudl, L. R., and Sherman M. I.: In vitro studies of mouse embryos bearing mutations at the $T$ locus: $t^{w_{\mathrm{w}}}$ and $\mathrm{t}^{12}$. Cell, 9: 523 (1976).

34. Received for publication May 8, 1978

35. Accepted for publication August 8, 1978. 